\title{
Human Anti-Sheep IgE Antibody Measurement
}

National Cancer Institute

\section{Source}

National Cancer Institute. Human Anti-Sheep IgE Antibody Measurement. NCI

Thesaurus. Code C98740.

The determination of the amount of human anti-sheep IgE antibody present in a sample. 